\title{
A RARE CASE: PELLET REMAINING IN THE PENIS AFTER SHOTGUN INJURY
}

\section{Nadir Görülen Bir Olgu; Ateşli Silah Yaralanması Sonrası Penis İçinde Kalan Saçma Tanesi}

\author{
Numan BAYDÍLLí1 ${ }^{1}$, Emre Can AKINSAL ${ }^{1}$, Hakan İMAMOGLU² \\ ${ }^{1}$ Erciyes University, Faculty of Medicine, Departments of Urology, KAYSERİ, TÜRKIYYE \\ ${ }^{2}$ Erciyes University, Faculty of Medicine, Departments of Radiology, KAYSERI, TÜRKIYYE
}

Firearms injuries to the penis are rarely seen but require immediate investigation to assess the extent of injury inorder to prevent complications such as erectile or/and urination dysfunction. Although the treatment is usually performed by surgical intervention, few patients can be followed conservatively. Herein, we present a case of a gunshot injury treated without any surgical intervention, in which a pellet was detected in the corpus cavernosum of penis and did not cause any symptoms of penile fracture. To the best of our knowledge, this is the first report in the literature regarding penile gunshot injury in which a pellet was retained in the corpus cavernosum and was treated without surgery.

Keywords: Gunshot injury, wound, penile trauma
Ateşli silah ile penis yaralanmaları oldukça az görülmektedir fakat sertleşme ve/veya işeme bozukluğu gibi komplikasyonları önlemek için, yaralanmanın hemen ve daima kapsamlı bir şekilde değerlendirilmesi gerekmektedir. Tedavi genellikle cerrahi bir müdahale ile olsa da bazı nadir olgular konservatif olarak da takip edilebilmektedir. Sunduğumuz bu olguda, ateşli silah yaralanması sonrası penis korpus kavernosum içinde kalan, herhangi bir penil fraktür kliniği oluşturmayan ve cerrahi bir girişim gerektirmeden tedavi edilen saçma tanesi olgusu sunulmuştur. Bildiğimiz kadarı ile ateşli silah yaralanması sonrası penis korpus kavernozum içinde kalan ve cerrahi bir müdahaleyi gerektirmeden tedavi edilen bu saçma tanesi literatürdeki ilk olgu niteliği taşıması bakımından dikkat çekicidir.

Anahtar Kelimeler: Ateşli silah yaralanması, yara, penil travma 


\section{INTRODUCTION}

Penile injuries with firearms are rarely seen because of the anatomic localization and mobility of the penis. The wound that is caused by penetrative trauma requires quick and attentive evaluation in order to rule out penile fracture (1). Fracture of penis is caused by a tear in the tunica albuginea of the penis often due to forceful manipulation, vigorous vaginal intercourse or masturbation, gunshot wounds, or any other mechanical trauma that causes forcible bending of an erect penis (2). Although the treatment is usually performed by surgical intervention, some eligible patients can be followed by conservatively $(3,4)$. Herein, we present a case of a gunshot injury in which one of the pellets remained in the left corpus cavernosum without any active bleeding and voluminous hematoma. The interesting point of the case is that the remaining pellet in the penis did not cause any symptoms and signs of penile fracture. No surgical exploration was required for removal of the pellet in the left corpus cavernosum.

\section{CASE}

A 26-year-old man admitted to the emergency service in July 2017 for firearm injury from a distance of 3 meters with a shotgun. Multiple numbers of pellet entrance wounds were seen in the right thigh on physical examination. A skin lesion on the dorsal surface of penis was detected. Most of pellets whose diameter was $2.5 \mathrm{~mm}$ were detected on the right thigh and pelvic region. Presence of a single pellet in the penis was confirmed by abdominal tomography. The remaining pellet in the penis is shown in Figure 1.

The pellets did not cause any skeletal and vital organ injury. Therefore, no further examination or interventions were recommended by orthopedics and general surgery. Although the lesion on the dorsal surface of penis was apparent, there were no signs and symptoms of penile fracture and penile tonus was normal on urological examination.
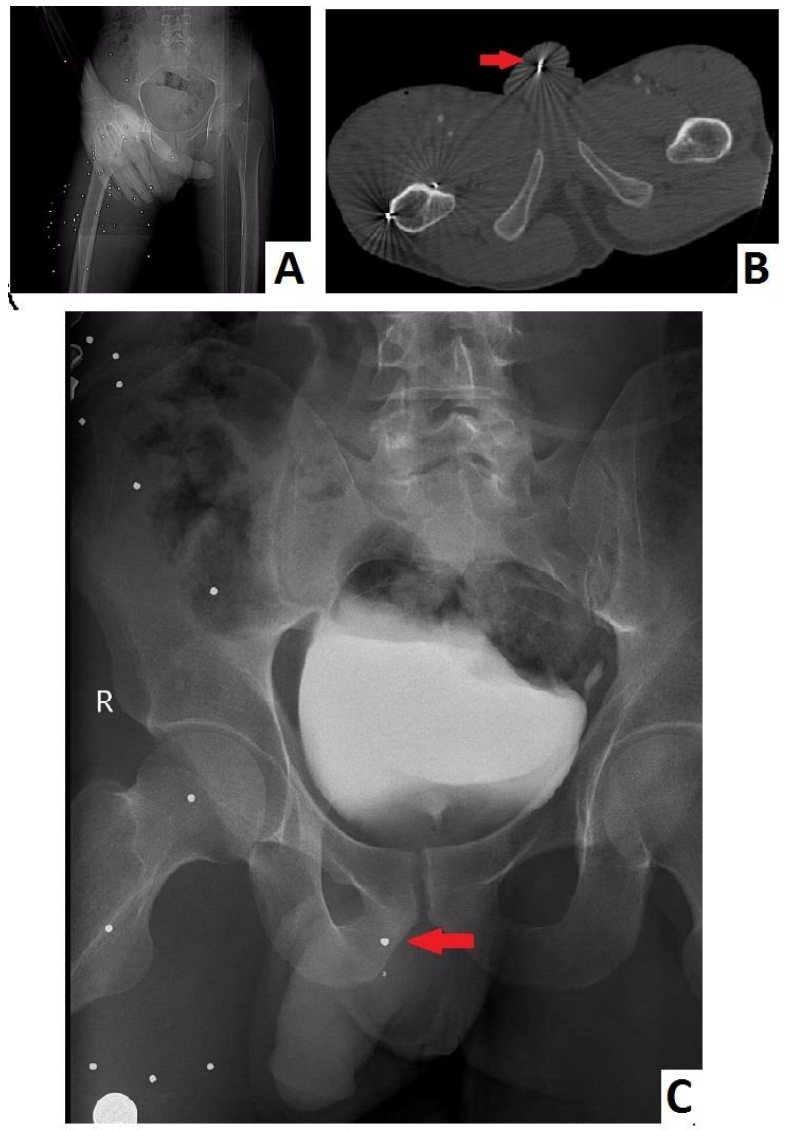

Figure 1: A. Images of pellets in the pelvic X-ray grapy in the emergency clinic B. Pellet in the penis was shown by computerized tomography in the emergency clinic C. Intravenous urogram (pellet in the penis was shown as red arrow)

No other genital or urinary pathology was detected. Patient had no hematuria and there was no blood in the anterior part of the urethra. Urethral passage was intact on the urethrographic examination. Because of the stable state of the lesion as well as the absence of penile fracture signs and symptoms, operation was not considered. Intravenous hydration, analgesic administration and ice-packs application were accomplished as symptomatic treatment.

At the subsequent visit after one month the patient had a scar on the dorsal surface of penis and no erectile dysfunction (Figure 2). However, he had a slight sense of stinging in the penis and this sense was irrelevant to erection. Penile ultrasound examination showed that the remaining pellet was in the left corpus cavernosum and had not migrated. It was also seen that the integrity of tunica albuginea was intact by penile ultrasound (Figure 3). 

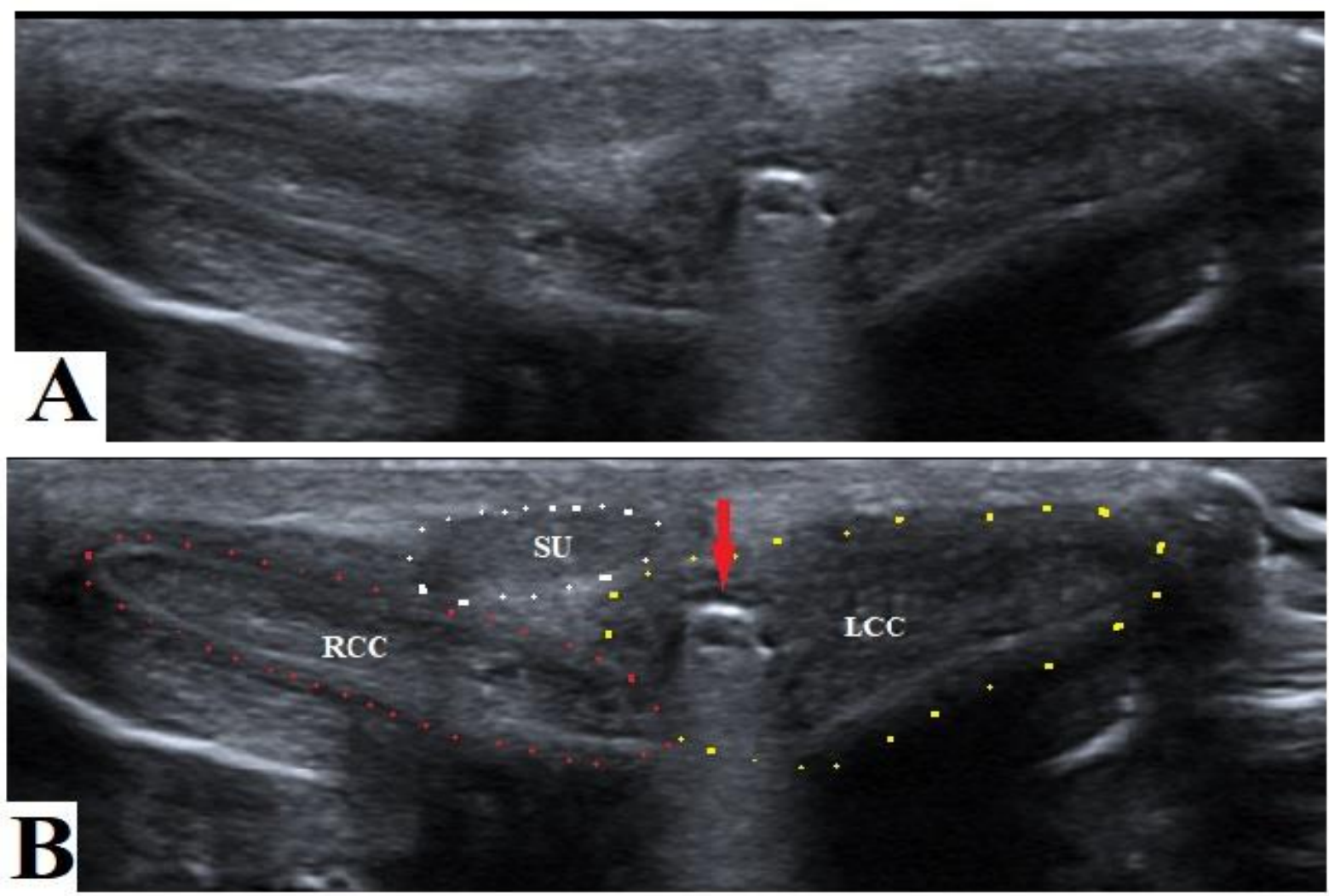

Figure 2: A. Remaining pellet in the left corpus cavernosum was shown by Penile ultrasound examination. (After one month) B. RCC = Right Corpus Cavernosum, LCC = Left Corpus Cavernosum, SU= Spongious Urethra, The integrity of left tunica albuginea was intact (pellet was shown as red arrow)

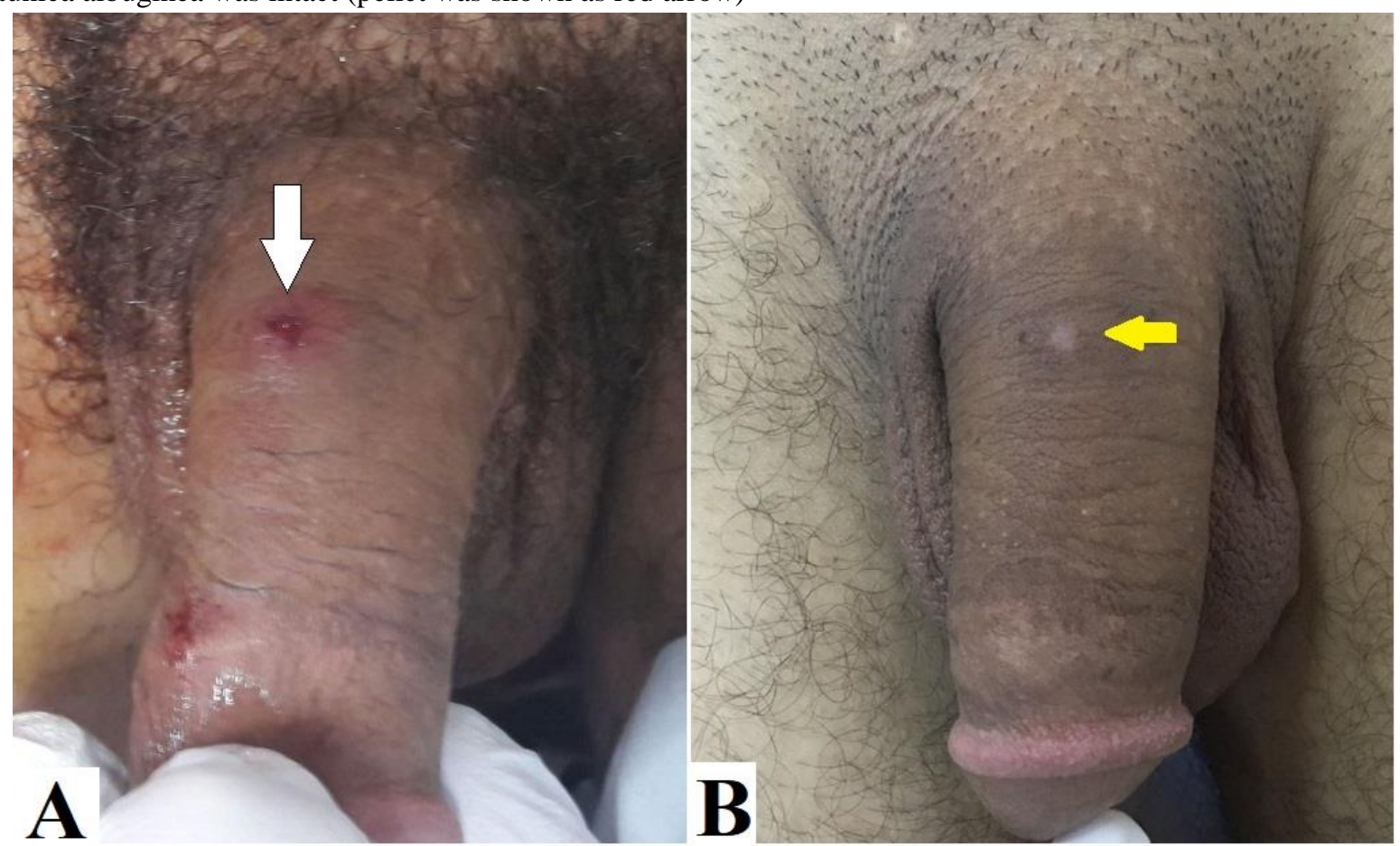

Figure 3: A. Wound of pellet on the dorsal surface of penis in emergency clinic (shown with white arrow) B. Scar of pellet on the penis was shown with yellow arrow. (After one month) 


\section{DISCUSSION}

Penile fracture caused by shotgun is a rare reason for consultation in the emergency clinic, which should be managed immediately. The presence of active bleeding or hematoma and disintegration of corpus cavernosum require closure of the albuginea's lesion and repair of the urethral lesions if detected (5). The section of Urological Trauma of European Association of Urology guideline (2017) remarks that subcutaneous hematoma, without associated rupture of the tunica albuginea, does not require surgical intervention. In these cases, non-steroidal analgesics and ice-packs are also recommended (6). Non-operative management is recommended in small superficial injuries with intact Buck's fascia (7). Our case had no signs of rupture of the corpus cavernosum and was followed up conservatively.

Wound of shotgun fired from close distance consists of a single wound with a large amount of tissue destruction, whereas at moderate distances there are multiple small wounds resulting from individual pellets. A scattered or peppered effect occurs with little injury when the shotgun is fired from greater distances. We think that the pellet may have entered to the corpus cavernosum at the detumescence phase of penile erection. As the pellets were fired from 3 meters, they were scattered to the right thigh. Due to the small caliber of the pellet and low intracavernosal pressure at detumescence phase, access hole in the corpus cavernosum may have closed spontaneously. Therefore, there was not a clinical sign of penil fracture.

In the literature, Ficarra et al. described a case of gunshot wound by two low-velocity bullets (3). While the first bullet caused a penetrating lesion to the testis, the second bullet remained at the root of right corpus cavernosum. This case has some differences from our case. Firstly, one of the bullets which penetrated to the testes required exploratory surgery. Secondly, diameter of bullet retained in the corpus cavernosum was relatively large caliber. Drainage of the voluminous bilateral scrotal hematoma and suturing of laceration of the right-testicle was performed for their case. Our case interestingly had no serious injury by shotgun and did not require any surgery. Ficarra et al. also reported that the patient regained a normal sexual function one month after the operation. Our patient described a sense of stinging in the penis occurring at any time on the first month on control examination.

After gunshot injury, some pellets may migrate to other parts of body after several years. Migrating and embolizing of bullets have been reported in the literature several times $(8,9)$. Therefore, pellet in the penis may migrate to the urethra and may be thrown out during urination.

Penile lesions caused by gunshot injuries often require surgical intervention. Some rare patients can be followed conservatively. In cases of shotgun injury, wounds and pelvic radiographs should be examined carefully keeping in mind that pellets which penetrate to the corpus cavernosum and remain in the penis may not require surgical intervention.

Acknowledgments: We thank Abdullah Gölbaşı and Ahmet Semih Güleser for taking photos of case and Oğuz Ekmekcioğlu for his contribution in editing and reviewing.

Conflict of interest: No conflict of interest was declared by the authors.

\section{REFERENCES}

1. Mohr AM, Pham AM, Lavery RF, Sifri Z, Bargman $\mathrm{V}$, Livingston DH. Management of trauma to the male external genitalia: the usefulness of American Association for the Surgery of Trauma organ injury scales. The Journal of Urology. 2003;170:2311-5.

2. Mirzazadeh M, Fallahkarkan M, Hosseini J. Penile fracture epidemiology, diagnosis and management in Iran: a narrative review. Transl Androl Urol. 2017;6(2):158-66. 
3. Ficarra V, Caleffi G, Mofferdin A, Zanon G, Tallarigo C, Malossini G. Penetrating trauma to the scrotum and the corpora cavernosa caused by gunshot. Urologia Internationalis. 1999;62(3):1924.

4. Gedik A, Kayan D, Yamis S, Yılmaz Y, Bircan K. The diagnosis and treatment of penile fracture: our 19-year experience. Ulus Travma Acil Cerrahi Derg. 2011;17(1):57-60.

5. Brandes SB, Buckman RF, Chelsky MJ, Hanno PM. External genitalia gunshot wounds: a ten-year experience with fifty-six cases. The Journal of Trauma. 1995;39(2):266-71; discussion 71-2.

6. Summerton DJ, Campbell A, Minhas S, Ralph DJ. Reconstructive surgery in penile trauma and cancer. Nat Clin Pract Urol. 2005;2(8):391-7.

7. Phonsombat S, Master VA, McAninch JW. Penetrating external genital trauma: a 30-year single institution experience. The Journal of Urology. 2008;180(1):192-5; discussion 5-6.

8. Jiachang W, Haien Z, Yuanguo L, Lei W, Zhoudan L, Hua Y. Gunshot Pellet Migration to the Right Ventricle: A Case Report and Literature Review. Indian J Surg. 2017;79(2):163-5.

9. Greaves N. Gunshot bullet embolus with pellet migration from the left brachiocephalic vein to the right ventricle: a case report. Scand J Trauma Resusc Emerg Med. 2010;18:36. 